\title{
Enhancing English Speaking Skills of Engineering Students in Virtual Classroom
}

\author{
A Poongodi ${ }^{1}$, J K Periasamy ${ }^{2}$ \\ ${ }^{1}$ Assistant Professor, SRM Institute of Science and Technology, Chennai, Tamil Nadu, India. \\ ${ }^{2}$ Associate Professor, Sri Sairam Engineering College, Chennai, Tamil Nadu, India.
}

\begin{abstract}
Every academic, professional or business job requires effective speaking skill. In fact, it is one of the skills essential for an Engineering student and it ensures placement in a good organization. Moreover, it is one of the important aspects in English Language teaching. In one's career, one has to encounter a number of situations, which demands effective speaking skills. One has to give oral presentations in meetings, conferences and seminars in front of higher officials or colleagues. Hence, one must know how to present one's ideas in order to attract the attention of the audience. This paper deals with the ways to improve one's speaking skills of engineering students in Virtual classroom.
\end{abstract}

Key words : Online Resources, Virtual Classroom, Interaction.

\section{INTRODUCTION}

Communicative skill is one of the essential skills to achieve success in one's career. In this world of technology, it is essential for students to improve LSRW skills. LSRW refers to Listening, Speaking, Reading and Writing. Language is the tool for communication [1]. Students acquire a language through the above mentioned skills. Speaking refers to sharing one's feelings or ideas to others. In English language teaching, improving students speaking skill is a challenging task [2]. In a classroom teaching, teachers encourage students to participate in group discussions, extempore or similar activities to make them speak. Covid- 19 has changed the lives of people drastically and teaching-learning is not an exception. Due to pandemic, classes are conducted online and English teachers job is all the more challenging. Virtuality takes the centre stage and online resources play a significant role in teaching-learning process [3]. This paper deals with the ways to improve the speaking skill of students using online resources.

\section{ROLE OF VIRTUAL CLASSROOM IN TEACHING}

Since English is the official language in most of the countries, it is important for a person who wants to achieve in his professional career. Proficiency in English language is the need of the hour. Especially for engineering students it is mandatory now-a-days. Though virtual classroom is not a replacement to the face-to- face classroom teaching, teachers have to adopt to the varying situation to avoid crisis considering the safety of the students. Various teaching methods are devised or analysed by the scholars for the effective online teaching-learning process. Computers play a pivotal role in teaching in the current situation. Traditional classroom is replaced with the Google Classroom and many other apps such as Kahoot, Mentimeter, Seesaw..., etc are utilized by the teachers for interactive sessions and to make the class interesting. As quoted by Settha Kuama in the journal article "Is Online Learning Suitable for All English Language Students?"

Online learning is student-centered because students can control their own learning pace, and activities can be flexible so as to better suit a student's preferred learning style. Online learning also creates opportunities for active learning (Dolence \& Norris, 1995). In addition, with good online learning applications or software, students have opportunities to participate in the discussion, express opinions, and share knowledge equally regardless of classroom size and time (Harasim, Calvert \& Groeneboer, 1997).

\section{ENHANCING SPEAKING SKILL IN VIRTUAL CLASSROOM}

Speaking is an art. One can master it by practice. A good speaker will always be in the limelight. It is essential for everyone, since sharing ideas give pleasure and happiness. To maintain a cordial relationship with people good conversational skills are needed. In formal setup like conference, meeting etc, speakers never begin with the topic, rather they initiate the conversation by breaking the ice, they talk about whether, food, travel etc., and then proceed to the topic of discussion. Making students to speak is a challenging task for the language teacher, since second language learners are anxious while expressing their views. Virtual classes reduce this anxiety as they are given the freedom initially to avoid facing the audience face-to-face and it is more advantageous. Furthermore, teachers can use any method depending on the flexibility of time. Due to pandemic, Virtual classroom is popular all over the world. Teachers connect with the students via internet. It gives the opportunity to students to learn from anywhere across the globe and provides 
a suitable ambience for learning. Here are few recommendations to enhance the speaking skills of the students through online.

Google classroom plays a significant role in online teachinglearning process. Some of the features are,

- White Board

- Chat

- Recording option

- Participant list

- Audio and Video

Teachers can make use of the above features effectively to enhance the speaking skill. Good listeners are good speakers. To speak fluently students should listen first. Through GCR, teachers can play audio and video and assign some tasks like quiz or presentation. Recording option provides opportunity for the teachers to assess or review their way of teaching. Further, students can replay the missed lessons or difficult concepts, which pave way for comprehensive understanding. GCR promotes interpersonal communication through which students can communicate with their fellow classmates without any fear and anxiety. It is wonderful platform for teachers to inculcate all the four skills (LSRW) among students. In a physical classroom, individual focus is not possible, but in virtual classroom teachers can monitor each and every student of the class. Marta Luisa Montiel Chamorro in her thesis states

The results suggest that the online course can provide an experience nearly identical to that of the classroom setting; the achievement was not significantly different between both classes, but the attrition rates were significantly higher in the online class, which is comparable to the results of other studies (Carr, 2000; McLaren, 2004; Ni, 2013). (p25)

Few suggested activities for enhancing speaking in Virtual Classroom

- Personal narrative

- Ted talk

- Role play

- Group Discussion

- Presentation on general and technical topics

- Just-a- Minute

- Debate

The above mentioned activities can be conducted in the virtual classroom in an effective manner. Initially, students must be exposed to the speeches by great personalities and questions should be posed. Then, some general topics should be discussed to make the students feel comfortable and reduce anxiety. Once they are accommodated, teachers should assign specific topics to students. It is always better to give pair or group work during initial hours. Finally students must be asked to speak individually. Teachers can use the white board tool provided in GCR for brainstorming.

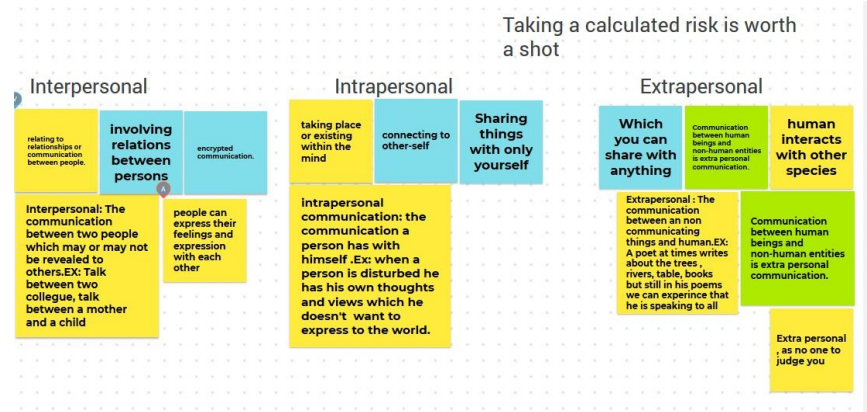

Figure 1: Whiteboard in GCR

The above figure 1 is an example of whiteboard. Students are given different types of communication for discussion and they are asked to discuss about it. Students participated enthusiastically and shared their perceptions.

\section{CONCLUSION}

The survey was conducted among the students with regard to effectiveness of virtual classroom in enhancing speaking skills. Majority of the students answered positively. Since Virtual classrooms are students-centred, they able to participate in interactive sessions without any hesitation. If activities are framed properly and students are monitored periodically, virtual classroom is a blessing for teachers as well as students.

\section{REFERENCES}

1. Kauma, Settha, "Is Online Learning Suitable for All English Language Students?", PASAA, Volume 52, July - December 2016.

2. Montiel-Chamorro, L, Marta. Comparing Online English Language Learning and Face-to-Face English Language Learning at El Bosque University in Colombia. Virginia Commonwealth University. 2018. Open access Theses and Dissertations.

3. Zimmerman, B.J. "Becoming a self-regulated learner: An overview". Theory Into Practice, 41 (2), 64-70. 2002. 